\title{
DOCUMENTÁRIO
}

\section{O BRASIL MERIDIONAL VISTO POR UNM OFICIAL DE MARINHA RUSSO NO INICIO DO SÉCULO XIX}

\author{
(Tradução e notas do Conde Emanuel de Bennigsen).
}

Reeditaram-se ùltimamente na U.R.S.S. as obras do almirante Golovnin (1), nas quais, para o leitor brasileiro, podem ser interessantes as descrições das suas escalas no pôrto de Nossa Senhora do Desterro (atualmente Florianópolis) em 1808 e em 1817 no Rio de Janeiro. Traduzimos os trechos em que êle fala do Brasil e juntamos, em nota, alguns dados biográficos sôbre a sua personalidade (2).

(1). - Vassili Goloviin, Obrax. Kảção do Departamento de Vias Marjtimug

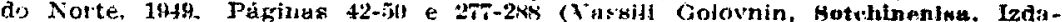
leistvo Glavsermorouti, 1919).

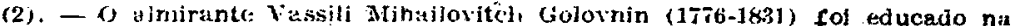
Hecola ae Cadetes da Marinh em retersburgu. Em 1700, sendo fadete. participou de algumas batalhas natis da guerra ruso-suech. Sm 1793 fol promovido $\Rightarrow$ sogundo-tenente e em 179.5 fol mandado com uma esquadra russi para h lncla-

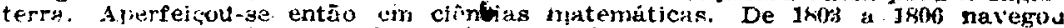
a bordo de navios ingjeses iésse pais era entât uliado du ¥Rugsia) sob o comando du almirante Nelgon. Curnwallix e Colling sood ti distingulu-se lelin sua corkfen. nia abordasens de navios fianceses. No din 25 de julho de 1 wor partia de Cronstadt.

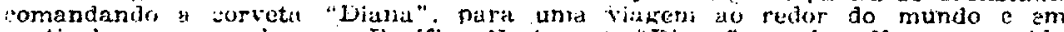
particular para explor"ar o r'ucffico Norte. A "Diana", porém, forit zonstruldx

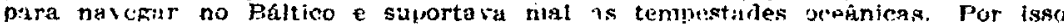
avancava con lentirão e chegou to tabo Horn nit pjor estaç̃o do ano e depois de 35 dias ie tentativas infrutiferas jara entrar no Oceano Pacifico, renuncion e viu-se olrigaco a utravessar outra vez o Atlantico uara chefar do bilrifico contornanilu a Africa. Mas nesse entretempo fol gssinudi th Paz de Tils!t.

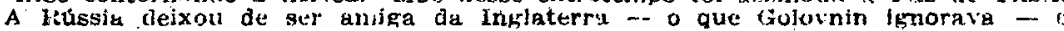
quando a "Lianr". en abril de lsox stiegrou à cldade do Cabo, fol detida pelos ingléses, conseguindo fugir de lä somente ell n:aio do ano seguinte. A fim th, vitar encontros com navios de guerra inflases. contornou a Austrália pelo gul c depois dirigiu-se no norte pura Kamtchatka. Lim jk10 explorou as costra du America to Norte e em 1 sil foi para as ilhas Curilas e Japdo. Quando desceu ni ilha Cuvasiri com dois oflciass equatro marinleiros para entrar en negoclaçes com as autoriflades japunesas, foi traicuciranente uprisionado. Isso se reu em mais de jN11 e soniente em uutubro de 1823 foi ele libertado. Voltou para Jetcrsblirgo por terra e chegua nessa capital om julho de 1514 . Tres anos majs tarde empreendeu uma outra vistem en redor do mundo que terminou em

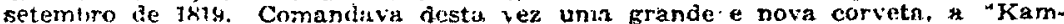
:chn'th:". a depois de entrar no porto do Rio de Januiro, contornoci o cabo Horn

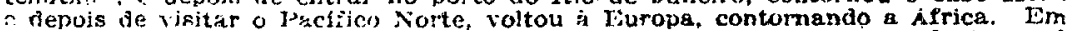
1821 foi nomeado diretur-adjunto do Corpo de Cadetes: em 181s intenuente-geral fa. Marinha; e em 18:31 fol promovido a vice-almirante. Morreu de cólera em 1833. (Nota do tradutors. 


\section{FIM DO CAPITULO "EM VIAGEM DA INGLATERRA AO BRASIL"}

As duas horas do dia 8 de janeiro de 1808 avistamos a costa brasileira e às 7 horas da noite distinguimos $\varepsilon$ ilha de Santa Catarina $\epsilon$ as duas pequenas ilhas situadas na entrada da sua baía - Alvaredo e Galera. Um vento contrário muito fresco nos impediu entrar ne. baía no mesmo dia; na manhã do dia seguinte continuou a calmaria. De todos os lades vimos inúmeras baleias na superfície das águas tranqüilas. Ao entrar na enseada, demos o sinal habitual para chamat o piloto e hasteamos nossa bandeira e bandeirola; entretanto ninguém veiu em nossa direção. Um guarda-costas português saiu então da baía zo nosso encontro com a bandeira hasteada, mas os fortins não hastearam bandeira: sem dúvida os portuguêses receiavam a saiva que ímos dar segundo os tratados, pcis teriam de respcnder a ela, e é mais que provável que näo possuissem pólvora ou então que tivessem tão pouco dela que não desejavam desperdiçar tal preciosidade. Uma vez estive antes a bordo de uma fragata inglésa em Faial, uma das ilhas Açores, que pertencern a Portugal. Ncsso cepitäo mandou à terra um oficial falar com o comandante para saber se a fortaleza ia responder à nossa salva por um número igual de tiros de canhāo. O bom comandante foi sincero e confessou ao oficial que ne fortaleza quase nāo havia pólvora; pediu portanto ao capitão para dispensar a salva. Lembrei-me dêsse caso e expliquei pelo mesmo motivo a falta de atençãc dos portuguêses, quando da nossa entrada; e a minha suposicão foi $\mathrm{m} \varepsilon$ is tarde confirmada.

\section{ESTADIA NO PORTO DA ILHA DE SANTA CATARINA E DESCRIÇÃO DESTA ILHA}

Não obstante o pilóto não ter chegado, entramos baía a dentro sem nenhuma dificuldade, graças ao mapa feito pelo capitão Krusenstern e que dêle recebera juntamente com outros, estampadós para sua viagem. Este mapa era: tão exato e tódas as elevações em marcos nas costas eram indicadas com tal precisão, que lcgo à primeira vista distinguimos todos os indícios pelis quais dirigimos nosso navi:.

No diá 9 de janeiro às 8 horas da noite lançávamos âncora na baía de Santa Catarine; já estava escuro. Entretanto, ao entrar no pôrto não poderiemos deixar de noter cs três fortins construjdos na foz da baía e o guarda-costa ancerado perto do litoral. Todavia a guarnição e os habitantes não nos deram nenhuma atenção e parecia que não havia habitantes nas margens desta vasta baía ou que êles tivessem fugido para o mato. Os portuguêses tal- 
vez sejam preguiçosos e incautos, mas não pcđáiamcs imaginar que à chegada de um navio de guerra (o que se dá ali muitas raras vêzes) não despertasse a sua curiosidade a ponto de vir à praia e lançar uma clhada para êste navio, tanto mais que êle trazia uma bandeira pcuco conhecida nestas paragens. $O$ deserto que representava êste vasto pôrto, cnde além do citado guarda-costas não havie nenhum navio nem canoa, o silêncio completo nas praias, as altas montanhas que circundam o pôrto, cobertas de mata virgem e a fraca luz desvanecente do crepúsculo davam a êste belo pôrto um aspecto tão selvagem e inabitado que os que não tivessem visto antes outres colônias pertencentes a Portugal custariam a acreditar que essa região tivesse sido algum dia habitada por europeus. Nas praias viam-se algumas choupanas, mas elas tão pouco pareciam hebitadas; ou talvez os seus habitantes estivessem profundamente adormecidos. Sòmente por cima do parapeito de terra de um dcs fortins vimos três ou quatro pessoas de poncho, mais não sabíamos quem er $\approx m$ : monges, mendigos ou soldados. Antes de entrar na foz da baia avistamos dcis camponeses, que trabalhavam ncs campos, situados nas vertentes das montanhas.

Depois de lançar a âncora, quis dar um tiro de canhão a fim de que os habitantes das pcroações circunvizinhas ficassem sabendo da chegada de estrangeiros e no dia ssguinte pudessem levarnos alimentos frescos, des quais tínhames grande necessidade. Mas antes de der ésse sinal chegou ao nosso navio um sub-cficial, mandado pelo comendante de um dos fortins, para saber quem éramcs, de onde e para onde iamos e porque tínhamos chegado. Elie não sabia nenhuma lingua iora do pertuguês e entre nós ninguém falav ミ esta língua. Todavia, com palavras que achamos no dicionáric, respondimcs satisfatòriamente às suas perguntas; a mímica ajudou-nos témbém a compreendê-1o: êle disse que ncssa chegada seria comunicada do fortim, por sinais, para o cidade de Nissa Senhora do Desterro, sede do governador, no dia seguinte. Após receber a resposta dêste poderíamoș ir à cidade e comprar tudo que precisássemos. Ele comunicou-nos que estava aí quando da visita a êsse pôrto dos navios "Nadejda" ("Esperança") e "Neva"; lembrava-se dos capitães Krusenstern e Lisianski e mostrou-nos o lugar, onde seus navios tinham ancorado.

Dispedimc-nos muito satísfeitos uns das outros, sabretudio porque entendemo-nos muito bem, $\mathrm{c}$ que foi devido, sem dúvida, ao nosso dicionário.

No dia seguinte ( 10 de janeiro), de manhã, mudamos de iugar e aproximámo-nos da praiz. O ajudante de cirdens que veio da fortaleza comuniccu-me que pori ordem do governador estávamos autorizados a desembarcar $e$ a ir a cidade comprar todos os mantimentos e outrcs objetcs de que precisávamos. Depcis das 9 horas fui visiter com $c$ meu ajudante o comandante da fcrtaleza. Por ordem deste, seu ajudante mostrou-nos o lugar onde poderiamos 
estabelecer nosses tendas para o observatório e não longe de lá um regato de água fresca.

Depsis do meio dia tivemos tempo de levar para a praia nossos barris vasios de água e estabelecer es tendas para a guarda e para os instrumentos astronómicos, que foram transportados para a mesma.

Além das melancias, levadas por uma canoa ao navio, não pudemos comprar nesse dia nada de fresco para a tripulação, apesar dos nossos esforços para encontrar alguma coisa.

Na noite do dia 11, nas montanhas e em cima de nós, houve uma forte trovoada e uma chuva torrenciel, durante a qual abateu-se uma rajada de vento terrivel que durou uns 15 minutcs; depois disso tudo se acalmou; ao levantar do-sol a berrasca tinha passado. Às 9 horas da manhã fui com nosso bote à cidade. $O$ comandante mandou um sub-oficial para me acompanhar e mostrar-me o caminho e $c$ pôrto. A distância do lugar cnde ficou ancoreda a corveta até a cidade era mais ou menos de 9 a 10 milhas.

Ac chegar em casa oo governador êste me racebeu imediatamente. Ele e seus ajudantes de ordens nãe sábiam ou não queriam falar o francês ou inglés (o primsirc fato era porém $m: i s$ provável) e por isso foi chamado um jovem português que conhecia bern a lingua inglésa afim de ser o nosso intérprete. Depois das perguntas habituais, versando sồbre a ncssa expedição $\mathrm{e} \equiv \mathrm{s}$ novidades políticas eurcpéias, Łu pedi autorização para ccmprar na cidade as alimentos e outras coisas necessáries para nós. O governador chamou imediatamente um das mais ricos comerciantes da cidade $e$ ordenou-lhe, na minha presença, ajudar-nos a achar tude o que precisássemcs. Entreguei ao governadcr a carta de recomendacaa para o conde dos Arcos, vice-rei no Rio de. Jansiro, a fim de transmitíla ao destinatário. Segundo meu pedido, o governader prometeu-me também mandar para o Rio de Janeiro a minha correspondéncia, a fim de ser mandada para Lisboa, de cnde poderia ser leveda para Petersburgo pelo ministro ou cônsul russo.

No seu tratar, nas conversas e no seu procedimento camigo o governedor deu prova de requintadá cortzsia e gentileza, sinais-infaliveis da sua boa educação. Convidou-me para o jantin, mas temendo perder un tempo precioso na preparação da corveta para a expediçàa, me desculpei, alegando que as circunstâncias me impediem ofe aceitar essa honra. O governador era um homem jovem, de uns 25 cu 30 anos de idade, de estatura pequena, mas um pouco desajeitado; entretanto tinha na fisionomia algo. de muito agradável.

Por curiosidade andei pelas principais ruas da cidade. Basta meia hora para ver tôda a cidade; ao todo tem umas 400 ou 500 casas. Tôdas elas são construidas de tijolos, pintades de branco e têm um ou dais endares com grandes janelas sem vidros. Não 
há nada dé notável na cidade que merecesse a atenção dos viajantes.

Após nos entendermos sôbre a preparação de todes os objetos que necessitávamos e dạr ordens para que tudo nos fôsse entregue - mais cêdo possivel, deixei a cidade e voltei para a corveta depois de 8 horas. Ccm grande prazer verifiquei que todos os trabalhos, tanto na praia como no navio, estavam sendo executados com grande presteza. O único aborrecimento era a falta de entrega dos mantimentos frescos pera a tripulação. Há bastante gado na regiào e êle é barato, mas os habitantes nāo o matam e não querem retaThar a carne. Só vendiam um boi vivo, suficiente para alimentar a tripulação inteira de um nevio de três conveses. Mas para nós uma perna de boi teria sido muito e com o calor do verão scb o 28.o paralelo, não era possivel conservat a carne nem por 24 horas; portanto tivemos de encomendar expressamente bezerros e porcos, que apesar de serem em relação ao seu pêso mais caros que a carne de boi, eram mais vantajosos do que êstes, dos quais teríamos que jogar a maior parte. Hoje demos a cada membro da tripulação sòmente um quarto de libra de carne de perco e a mesma quantidade de peixe, que compramos aos habitantes.

Dois estrangeiros estabelecidos aqui nos ajudaram muito a comprar os mantimentos: um era alemãc e o outro irlandês. Cada um dêles nos contou a história da sua vida e sua situação atual. O que contam semelhantes pessoas não passa geralmente de fábulas inventadas, repletas de estranhas aventuras. Seu alvo é apenas dispor cs recém-chegados a seu favor. Todos êstes vagabundos que abandonam a pátria afim de arrumar sua vida pela fraude e pela astúcia ou servindo a paises estrangeiros, sempre contam aventuras maravilhosas, suscetiveis de atrair a atençãc e levar os ouvintes a ter pena déles; aliás, não dei nenhum crédito a tudo que élss ccntaram. Pelo conbecimento da lingua portuguésa nos foram úteis; quantc aos seus serviços, os paguei pontualmente, prccurando não șer enganedo pct êles e não thes demonstrei a menor dúvida ou desconfiança $\epsilon \mathrm{m}$ relaçâo a sua honestidade.

Apesar do calcr terrivel, trabalhamos desde 0 amanhecer até a ncite cair.

O mais difícil para nós foi tirar do mato uma árvore que tínhamcs derrubado para substituir uma verga do traquete e trazé-la para a praia. No dia 15 o nosso carpinteiro-chefe escolheu, cortou e limpou esta árvoré. Perto da praia não havia árvcires de altura necessárla; aquela que servia estava numa espessa floresta a uma distância de umas três versts (3) da praia. Fó necessário puxar a. árvore através do mato e da capoeira para um terreno irregular. Foi preciso ccrtar outras árvores ou tocos, passar per barrancos ingremes e puxá-la por cima das pedras. Eta impossível trabalhar à noite, portanto executamos tcdo êsse trabalho durante o dia. $O$

(i). - Lina verst o um pouco major que um qullómetro. (Nota do tradutor). 
die 16 foi totalmente ccnsagrado a êsse labor que 0 calor exces sivo tcrneva insuportável. Os homens trabalhavam num mato espesso cnde reinava uma calma absoluta e onde nãc se sentia o mínimo sôpro de ar. Os raios quase verticais do sol penetravem tôda a floresta e năo havia lugar cnde se podesse esconder dêles. O calor era mais insuportável do que ncs banhos turcos. Todavia nossos homens executaram do coméço até o fim êsse trabalho penoso sem descansar e até com alegria e sem visivel cansaço.

No dia 18 de janeiro levamos da praia os instrumentos astronômicos, a tenda e todos os nossos apetrechos e aprontamo-nos para embarcar... .

Continuarei mais adiante a narraçāo da nossa viagem depois da partida dc navio. Quero inserir aqui sòmente algumas cbservaçóes a respeito do pôrto da ilha de Santa Catarina. Quase ao mesmo tempo que deixamos o pôrto da ilha de Santa Catarina a côrte portuguésa abandonou a Europa e chegou à América. Escolheu o Rio de Janeiro para residencia da família real e sede do govêrno. Em conseqüência déste importante acontecimento político o Brasil tomcu um aspecto completamente diferente; além da reorganização das instituições internas, o comércio brasileirc, antes interditadio a todes os povas, exceto aos portugueses, abriu-se logo aos ingléses e o pôrto de Santa Catarinar foi desde o início escolhido como ponto de reunião dos navios mercantes dêste povo. Os inglèses sendo neste período banidos e excluídos do comércio europeu, lançaram-se para tôdas as regiōes, mesmo cnde tinham a menor esperança de obter lucros e por isso o Brasil encheu-se imediatamente dos seus negociantes e dos seus produtos manufaturados. A mundança dos preços de diversos produtes extraídos no Brasil foi uma consqüència normal dêsse acontecimento e por isso o pôrto de Santa Catarina: tomou logo um aspecto bem diferente daquêle em que achámo-lo. Minha descrição refere-se assim ao tempo quando o Brasil não era ainda um reine independente, mas só uma colónia de Portugal, administrade de modo bem diferente do que egera.

\section{A SITUAÇÃO, A HIDROGRAFIA E AS FORTIFICAÇÕES DO PÔRO}

A ilha de Santa Catarina está situada mais ou menos entre $27^{\circ} 19^{\prime}$ e $27^{\circ} 50^{\prime}$ de latitude sul; sua maior largura é de 6 milhas. Dois promontórios avançam em direção a 0 e $W$, um da ilha, outro da terra firme, sendo a distância de um ac outro de um quarto de milha. Este canal forme a entrada sulina do pôrto que serve sòmente para pequenos navios. A extremidade do norte da ilha está a uma distância de $6 \frac{1 / 4}{4}$ milhas do continente, seguindo o paralelo.

Desta linha ccmeça, por assim dizer, a entreda do pôrto. Seu limite era 20 norte entre o fcrtim de Santo Antônio que se acha 
na ilha de Santa Catarina e um outro fortim, denominedo Santa Cruz, construído numa ilhota separada da terra firme por um canal de largura não superior a 150 sagènes (4). A distância entre êsses fortins é de $3 \% / 4$ milhas. Eles formam a defesa da entrada norte do pôrto, a mais importante para todos os navios. 0 comprimento do pôrto desde a entrada norte até a do sul é de $93 / 4$ milhas e a largura máxima é de $61 / 2$ milhas mais ou menos, mas nem todo êste espaço está apto a receber grandes navios.

Este pôrto é um dos mais seguros de todo o mundo. Pcde abrigar a maior frota de guerra ou mercante. O fundo é todo coberto de lodo; não há nenhum escolho, nem banco oculto; sua profundidade diminui pouco a pouco em direção às costas. $O$ pôrto está ao abrigo de todos os ventos, excepto do NO, mas dêste lado nunca há ventos fortes. Nos meses de inverno há no hemisfério meridional ventos do sul muito fortes, mas que não duram muito e nãe podem ser perigoscs, pois o pôrto está completamente fechado do sul e sua profundidade não é grande; de mcdo que o vento não pode levantar grandes ondas. Não há rios que esccam na baía, mas das montanhas descem muitos córregos, tanto em: terra firme, como na iha. Em alguns dêles a água é completamente transparente e tem gôsto muito agradável.

A cidade de Nossa Senhora do Desterro está situada na margem sul do promontório da ilha Santa Catarina, na extremidede do qual foi construido o fortim São João. A distância entre a cidade e o fortim é de uma meia milha mais ou menos. A pequena baia que está na frente da cidade não é bastante profunda para grandes navics. Entretanto, na enseada diante dela, estavam ancorados dois ou três navios portuguêses destinados ao comércio de cabotagem. Isso se dá sòmente no verão; pois no inverno é perigosc para os navios enccrar ali, porque a enseada está completamente aberta acs ventos do sul.

Além da cidade, nas margens da baía, há duas outras povoações. Uma se acha em terra firme e a outra na ilha. Além disso, ao longo de tôdas as costas estão disseminadas várias cases a certa distáncia uma da outra; no interior, segundo dizem os habitantes, não há nenhuma povcação perto. As montanhas e vastas matas virgens intransitáveis, habitadas por feras e cobras venenosas, impedem as comunicações para o interior.. Por isso os habitantes constroem suas casas à margem das baías ou nas fozes e nas margens dos rios navegáveis; tôdas as ccmunicações entre povoaçōes próximas ou distantes se fezem pela água. Mesmo os vizinhos que morøm nas costas dessa baía, a uma distância de meio quilômetro, us $\approx m$ canos (assim se denominam pequenas embarcaçōes feitas com o tronco de uma árviore), para fazer visitas uns ács outros. Acham mais fácil comunicar-se desta maneira do que atravessar o 
mato, no qual nem sempre há sendas: Até o ccrreio é mandado por mar.

Essa provincia pertence ao vice-reino do Rio de Janeiro e tem comunicação por terra só com o Rio Grande por um rio situado ao sul de Santa Catarina a uma distancia de 240 milhas mais cu menos. Nos vales da vizinhança dêsse rio há muito gado vacum que levam até lá por uma eștrada que segue a beira-mar. Na cidade vi muitos cavalos que são usados, como me disseram, mais para a equitação do que para grandes viagens e para o trabalho. Da aldeia de Santo Antônio existe uma boa estrada para a cidade e na aldeia há carruagens para viajar.

As construçóes dos fortins foram deixadas sem cuidado e estão em péssimo estado. Acrescentamos que não possuem um número suficiente de canhōes. Mesmo os čnhōes que estão em algumas baterias näo parecem bons para serem usados. Foram fundidos no século XVII ou talvez antes e foram ccmpletamente abandonados. Com o tempo a ferrugem os tornou imprestáveis. Além disso, também as carretas apodreceram.

No que se refere à guarnição, ela anda ao par das fortificaçóes. No fortim de Santa Cruz, onde mora o chefe da fortaleza, verificamos tóda a sua fôrça. Parecia que os soldados saíam sòmente para observar quando entrámos pelo pôrto. Examinaramnos com curiosidace. Admitindo que sòmente a metade dêles saiu. impelida pela curiosidade, tóda a guarnição não deve ultrapessar 50 homens.

Suas fardas ou suas roupas parecem de mendigos. Os soldados estão quase todos descalços; as espingardas das sentinelas estão cobertas de ferrugem. As fisionomias pálidas e famitas revelam. com evidéncia que eram tropas portuguésas. Não poderia ser escrita uma sátira mais cáústica e forte sôbre a classe militar do que representar um quadro $\mathrm{ccm}$ tal figura escrevendo em baixo: "soldado".

Na cidade, porém, fiquei espantado com a guarda do governador: a estatura jos homens, seu aspecto, suas roupas e armas estavam em tal estado, que raão sommente nas colónias portuguêsas das ihas, como também em Lisboa, não vira soldados da guarda do rei täo bem apresentados. A verdade é que êles eram muito poucos e é possivel que o governador mantenha sua guarda pessoal em meihor estado por conta dos outros militares que the são subordinados.

AS VANTAGENS E AS DESVANTAGENS QUE A BAFA DE SANTA CATARINA OFERECE AOS NAVIOS QUE NELA ATRACAM.

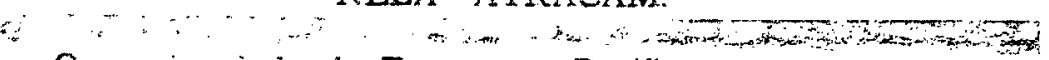

Os navios, indo da Europa ao Pacífico e que atravessam o Atlántico. tém de entrar pelo menos num pôrto para abastecer-se. je úgua doce e mantimentos frescos e dar descanso à tripulaçãc. 
Para tal há quatro portos: as ilhas do Cabo Verde, o cabo da Boa Esperança, o Rio de Janeiro e a ilha de Santa Catarina. Os que navegam pela rota oriental, isto é, contornando o cabo da Boa Esperança, escolhem geralmente os dois primeiros; ao passo que os que pretendem penetrar no oceano Pacífico pela rota ocidental, contornando o cabo Horn, atracam num dos dois últimos. Falarei aqui só da baía de Santa Catarina e sòmente daquilo que vi com meus olhos e conheci por experiência própria.

A situação geográfica dêste pôrto é uma das suas vantagens principais: está no caminho, tanto dos navios que navegam em direção ao Pacífico pela rota ocidental, quanto pela oriental. As costas vizinhas não têm bancos de areia e escolhos; é fácil e seguro chegar ao pôrto em qualquer estação e com qualquer vento; a sonda sempre marcará a distância exata. A entrada do pôrto está completamente livre, não apresentai nenhum perigo e achá-la, vindo do alto mar, não é difícil.

A principal vantagem dêsse pôrto para os navegadores (vantagem que êles não devem perder de vista) é, porém, a fartura dos diversos gêneros alimentícios frescos e a preço moderado.

As leis de Portugal proibiam aos seus súditos brasileircs não sòmente comerciar com os estrangeiros, mas também com os portuguêses fora dos dois portos principais - Salvador e Rio de Janeiro. Todos os produtcs eram levados para êstes dois portos em pequenos navios de cabotagem e de lá mandados para a Europa em grandes comboios; portanto os demais portos não têm comércio próprio: Ali não há ricos negociantes, nem emprêsas comerciais e êles são pouco povoados; por causa disso os produtos aí produzidos são baratíssimos. Os principais são o arroz, o café e a pesca das baleias. Há em Santa Catarina um grande engenho para a explcração total das baleias. O direito de pesca, foi concedido pelo govêrno a uma companhia de negociantes e é muito lucrativa Ao chegar vimos grande quantidade de baleias quase na entrada da baía.

Dizem que o café local é o melhor de todo o Brasil. A terra produz também muito açúcar; as verduras e frutas crescem em grande quantidade. Encontramos melancias, abacaxis e bananas maduras. Os limões e as laranjas estavam ainda verdes e pequencs; há muitas abóboras e gostosas.

Há bastante gado vacum e porcos, mas nãọ vi carneiros. Trazem o gado das margens do Rio Grande. Ali existe tanto que o matam sòmente para curtir o couro. Das aves domésticas há muitos perus, galinhas e patos. Há muitas aves selvagens, segundo dizem os habitantes, nos lagos e nas baixadas. Os habitantes contam que em certas épocas do ano os peixes entram na baía cos bancos; a pesca então é abundante. La Pérouse esteve aqui em novembro 
e escreve que durante sua estadia bastava jogas a rede para tirála cheia de peixe. Quanto a nós não fomos tão felizes. Não pescamos quase nada com os anzóis e com a rede retirámos em três horas no máximo uns quarenta peixes; eram do tamanho de um harenque, mas um pouco mais cheios e mais gcstosos. Não tiveram maior exito os nativos, que pescavam com anzóis dos seus botes ao nosso lado. Começavam geralmente a pescar desde manhã cêdo e ao meio dia levavam os peixes para nos vender e nunca vimos muito peixe nas suas canoas.

A baía de Santa Catarina tem mais uma vantagem: o gênio bom e pacífico da gente que mora nas suas margens. Esta gente é supersticiosa, preguiçosa e pobre, mas honesta, amável e serviçal. Não nos roubaram nada, nem tentarem fazê-lo, apesar de apresentar-se a ocasião. Às vêzés, pediam por aquilo que vendiam mais do que para os seus patricios, mas a diferença era muito pequena. Aliás era muito natural: onde é que os habitantes não se aproveitam da ignorância e da inexperiência dos estrangeiros? Em sua honra quero ainda acrescentar que ao fornecer na corveta mantimentos frescos, verduras e frutas e serem pagos nos primeiros dias quase sem regateer, êles não procuraram aumentar os preços, o que teria sido fácil, inventando algum pretexto. Todavia, os alemães e inglêses estabelecidos aqui, não possuem a mesma simplicidade.

Tenho de apcntar ainda as desvantagens dêsse pôrto. Na.minha opiniāo são duas: uma permanente e outra temporária. Não há ali nem arsenal maritimo do Estado real, nem estaleiros particulares, de modo que ninguém constrói navios nessas paragens; por isso é impossivel encontrar equipamento marítimo e artesões. Portanto, o navio que sofrer consideráveis svarias não pcderá receber nenhum auxilio neste pôrto e terá de executar os consertos com seus próprios materiais e seus homens, c que não é sempre possivel, pois às vêzes não se pode fazer nada sem as instalações de um estaleiro; além disso é muito difícil achar a madeira desejada. Eu já disse quanto trabalho nos custou trazer para a praia uma árvore para uma verga do traquete de 34 pés. Nas montanhas cresem ótimas árvores: não sei como as dencminam cs botânicos, mas os navegadores as conhecem como pau brasileiro. Ele é avermelhado, muito duro e quando verde, é tão pesado, que afunda na água.

Quanto à desvantagem temporária, dela sofrem os navics apenas em fins de fevereiro, em março e abril depois do calor excessivo do verão. Há então surtos de doenças epidêmicas, cujas consequiências são às vêzes funestas, sobretudo para as pessoas não acostumados a êste clima. Salientamos todavia que isto é bem diferente aqui do que se dá em outros lugares da América ou da India Ocidental, cnde a febre mortífera e contagiosa devasta cada ano povoaçōes inteiras. Aqui đizem os habitantes não é todo ano que tais doenças apresentam perigo. 
II

Na aurora do dia 5 de novembro avistamos a entrada do Rio de Janeiro (5), na qual entramos-mais ou menos ao meio dia. Na entrada demos salvas ao fortim Santa Cruz e, em conformidade com os tratados, recebemos um disparo em resposta de cada um dos nossos, quando entramos completamente na baia. Vieram ao nosso navio dois oficiais portuguêses em dois botes diferentes a fim de saber quem éramos, de onde chegávamos, etc. Um dêles era da polícia marítima e, o outro, capitão de marinha e ajudante de ordens do rei. Ele nos visitou, pois tinha por obrigaçắo fazer relatórics ao rei da chegada de todos os navios de guerra estrangeiros.

Após lançar as âncoras mandei imediatamente dois oficiais à cidade em busca: do nosso cônsul geral, que, à noite, veiu ver-me com êles. Combinamos com êle a melhor maneira de abrstecer a corveta de tudo o que ela necessitava, a fim de continuar nossa viagem sem perda de tempo. Soube com grande prazer que no dia 8 do mesmo mês um navio inglês ia partir diretamente pare a Inglaterra e que neie ia viajar um corhecido do cônsul, que levaria a minha correspondência a Londres.

Na manhã do dia 6 lançamcs duas âncoras e depois disso desambarquei com os oficiais, jantej em casa do nosso cônsul geral e passei o dia todo com êle. Sua casa nos subútbios era urn lugar encantador.

Nada disse ainda da cemperatura atmosférica do ar, que tivemos durante a nossa travessiz; fomos muito felizes pois nấ houve nem grande calor, - neln frio e durante a viegem a corveta nõo sofreu nenhuma avaria e chegou ao Rio de Janeiro em bom estado, do mesmo modo que a sua tripulação.

Permaneci todo o dia 7 de novemibro na corveta prepázando as cartas que às 6 horas da tarde entreguei ao cônsul geral para serem enviadas a Loridres. Dei-lhe também a lista dos gêneros alimentícics de que precisáve mos, pedindo que os conseguisse o mais cêdo possivel.

Nesse dia visitou-nos de novo o capitão da marinha, ajudente de ordens do rei. Ele me declarcu que sua majestade estava encantado de ver em sua capital um navio de guerra do imperador da

(5). - No dia 25 de agósto de 1817 Golovin purtia de novo de Cronstadt para una. viagem de exploraçâo do norte do Pacifico. Comandava desta vez uma w;rande corveta, a "Kantcinatka", que alcançou ràpidamente as costas do Braajh. Na manhí do dia 4 de novembro chegou perto do Cabo Frio e na manha do ija 5 a proximou-se Go Rio de Janeiro. Na travessia de Portsmouth para o 13resil Enure um encontro curioso. Na noite do din 12 de outubro toi avlatado pelo "Kamtchatka" um grande navio que imaginaram ser um corsario dos Insurre. to esvaribois da América do Sul que, gesundo noticias inglesas, atacavam navios â tóas as nacionalidades. Portanto, foram toinadas medidas de precausăo e o vivio russo preparou-se para a bitalha. Toda a noite os dois navios não se verderam de vista e somente de maribâ ficou estabelecido que o "coreario". "erat uJ nuvio de zuerra inglés gue, por sua vez, Euspeitava ser o "Kamtchatka" um "orsario. Aconteceu que o comandante do navio ingles era um velho amigo do Golornin e depois disto os dols navios navegaram juntos até as costas brasileira.

(Nots de tradutor). 
Rússia, que êle muito respeitava $e$ que 0 rei tinha dado ordens para que nós fôsse prestada tôda e qualquer ajuda de que precisáșsemos.

Pedi ao ajudante de ordens exprimir a sua majestade minha gratidão e declarei que acreditava ser meu dever tornar ciente meu governo desta amabilidade; porém, tendo sido bem abastecido de tudo em nossos portos, não necessitava de tal ajuda.

Esse ajudante de ordens do rei me deixou a impressão de um homem muito bom e serviçal; sua erudição, porém, nãc era muito grande. Avistando no meu camarote um crucifixo, de repente, pôsse a fitá-lo com grànde espanto e exclamou: "Mas éste é Jesús Cristo?" - "Sim, senhor!" - "Então o senhor crê no Cristc?" "Naturalmente!" - "E tcdos os russos creem?" - "Não há dúvida, todos os russos creem", respondi com espanto. "O senhor não sabia disso?" - "Nunca ouvi, disse êle, que os russos fôssem cristãos, sempre imaginara serem êles gregos". Sem dúvida pensava que éramos pagãos e crímcs em Júpiter, Mercúrio e outros deuses.

$\mathrm{Na}$ noite do mesmo dia, nosso cónsul mandou dizer que sua majestade em resposta ao seu pedido de audiência dignou-se responder que teria imenso prazer em receber, a mim e aos meus oficiais, logo que melhorasse de uma indisposição de que sofria e que o dia para tal cerimónia seria marcado por éle.

Apesar de ter sido curta a travessia para o Rio de Janeiro, o fato é que tínhamos' atravessado todo o cinturão quente saíndo de um -clima frio e tudo isso com muitas chuvas, de maneira que a parte superior da corveta precisava de alguns pequenos reparos, do mesmo modo que o cordame e as velas. A tripulação tratou dêsses reparos assim como do transpcrte de água doce. Nessas ocupações os portuguéses não nos prestaram nenhuma ajuda que, é verdade, nem tínhamos pedido. Pedi apenas que nos trouxessem água doce em barcos maiores do que os nosscs; o ncsso cônsul recebeu do ministro da marinha em respesta a sua carta, mandada alguns dias antes, a informação de que tinha sido dadas ordens para nos mandar imediatamente água dcce: entretento não a recebemos nos dias seguintes e continuamos a transportá.la em nossos botes a remo e com ncssa gente. Tais são os portuguêses com as suas promessas e a sua ajuda! De início tinham oferecido êles próprios em nome do rei e do comandante do pôrtc ajudar-ncs, mas numa coisa tão pouco importante quanto o transporte de algumas toneladas de água dore, não quiseram trazê-la do fôrto, onde tém para isso navios apropriados e tôdas as comodidades. Fiquei contente, aliás, que êles não nos tivessem dado água, pois êles teriam dado a essa pequena coisa a importância de um grande favor e teriam obrigado nosso encarregado de negócios a fazer a êsse respeito uma representação ao czar, impelindo-o a oferecer uma condecoração russa a um funcionário qualquer. Em geral, o melhor é não pedir favores a ninguém em portos estrangeircs quando se pode dispensá-los. 
Todavia, todos foram bastante corteses. O comendante da esquadra, que estava entāo no pôrto, mandou seu capitão nos dar as boas vindas $e$ oferecer-nos os serviços que dependiam dêle. $O$ segundo comandente veio mesmo nos fazer uma visite, antecipando a minha. Os comandantes de duas fragatas austríacas que acompanharam de Livorno até aqui a arquiduquesa, espôsa do príncipe herdeiro do Brasil (ela tinha chegado a bordo de um navio de linha português); também me deram a: honra das suas visitas e na mesma hora da nossa chegada, mandaram-me oficiais oferecer seus préstimos e sua ajuda, dos quais, porém, não tivemos a menor necessidade.

Durante nossa estadia no Rio de Janeiro, quando nossas ocupações o permitiam, iamos sempre à cidade e seus arredores para visitar o que ela tinha de interessante. No dia 9 de novembro, eu e a maior parte dos nossos oficiais tomamos carros de aluguel e visitamos quase tôda a cidade, guiados pelo cônsul russo que nos acompanhava e tudo explicava. Como já estive na India Ocidental, não me espantcu a situação dos pretos no Brasil, mas os meus ccmpanheiros ficaram muito admirados com $o$ ' assim chamado "mercado dos pretos": é uma rua comprida que se chama Volonga (Via Longa?), onde em cada casa há uma loja, na qual não há outra mercadoria, senão pretos para serem vendidos. Estão êles sentados em bancos e os fregueses chegam, os examinam, os apalpam, informam-se a respeito da sua saúde, regateiam e os compram como qualquer gado doméstico.

No dia 11 de novembro o ncsso cônsul nos convidou a $\mathrm{mim}$ e a alguns oficiais e cadetes da marinha, para ver uma cachoeira, a uns 25 quilômetros da cidade, lugar muito bónito. No fim de um vale largo, fértil e muito bem cultivado encontra-se essa queda dágua, que cai sôbre dois terraços; cada um dos quais tem $\approx$ altura de 80 metros. Ao lado da cachoeira, sob uma enorme pedra, há uma gruta na qual dcis nichos estão esculpidos na pedra, encontrandc-se ainda uma mesa e bancos feitos do mesmo material. Aqui, dizem, escondeu-se há uns cem anos, durante o assédio do Rio de Janeiro pelos franceses; o bispo local com seus padres, celebrando aí as missas (6). Na mesa os visitantes recortam os seus nomes. Almoçamos aí mesmo e ficamos até o nosso pintor Tikhonof (que acompanhava a expedição) terminar um desenho da cachoeira. Depois voltames para casa a meio caminho da ci$\mathrm{d} \varepsilon \mathrm{de}$, onde tínhamos deixado as carruagens. Tínhamos ido a cavalo até a cachoeira, pois essa parte do caminho era montanhosa e tão ruim, que sòmente se podia atravessá-la com cavalos acostumados às montanhas. Nessa casa a meio caminho nos esperava a espósa do cônsul. Jantamos ali e voltamos para cidade só à noite.

(i). - Os francests tinlaim desembarcado tropas num profundo braço de mar a oeste da cidade; colocaram baterias nas colinas e ameaçavam queimar i. cirlade, combardeando-a; mas o vice-rei consentiu em salva-lu, pagando unia frande quantia. Após serem pegos, os franceses afastaram-se imediatamente. 
Este caminho pode ser comparado com a estrada de Peterhof (7) porque, após sair da cidade e até as montanhas, há de ambos os lados da estrada casas de campo dos ccrtesões e de pessoas de pcsse. As casas são aqui geralmente pequenas mas os jardins vastos e lindos. Mas êstes jardins nào constituem algo de extraordinário: todo o. Brasil é um jardim.

No dia 16, Langsdor comunicou-me que o rei nos receberia no dia seguinte; à noite, no seu palácio de verão, para onde deviamos dirigir-nos às 6 horas e meia, afim de estarmos aí às 8 horas (8).

Preparávamo-nos para sair, quando o cónsul comunicou-me que o rei tinha recebido noticias de uma revolta em Lisboa e transferira. nossa recepçāo para segunda-feira, dia 19. (Após essa revolta foram enforcados em Lisboa Gomes Freire e alguns funcionários do. Estado). Todavia, como estávamos prontos para sair ao mar e como tencionávamcs partir no dia seguinte, não pensávamos mais ter a honra de ver sua majestade. Entretanto, no dia 17 o tempo piorou: soprava um vento de sul-oeste que nos impediu de partir; de maneira que no dia indicado; às 7 horas da tarde, fui $\mathrm{ccm}$ cinco oficiais e o cônsul para o palácio de verão, distante do Rio de Janeirc sete cu oito quilómetros (9). Quando chegamos 0 rei estuva na igreja assistindo a reza. Permanecemos de pé na porta da igreja e esperamos quase uma hora; ouvimos a música real e o côro: tocavim e cantavam muito bem, mas estranhamos ver que tanto os músicos como os cantores, entre os quais havia muitos pretos e mulatcs, estavam trajados de qualquer jeito e em geral muito mal.

Depcis da missa o primeiro camateiro do rei, trajedo com uma rica farda vermelha, com duas condecoraçōes, anuncicu-nos e, depois de esperarmos um quarto de hora numa galeria, abriu-se de repente a porta que dava para uma enorme sala na extremidade da qual havia algo parecido com um trono emoldurado de cortinas brancas. A sala era muito mal iluminada. O rei, num unifcrme azul com duas condecoraçóes, faixa, espeda e uma bengala, estava de pé, ao lado de uma mesa, com seu camareiro atrás. Segundo a etiqueta da côrte portuguêsa, curvamo-nos ao entrar na sala diante do rei, na metade da sala curvamo-nos outra vez e, epós aproxi-

(1). - Feterhor - residéncis buperial de verũo nas vizinhanças de petera-

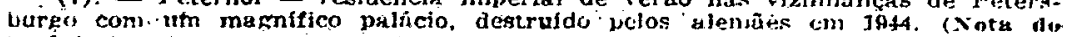
tradintor).

(\$). - Golovnin nă tinhy dito ainda que o consul do qual falwin ern

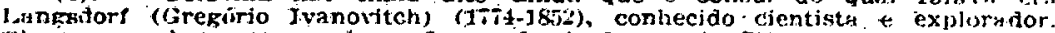
Fif erm n:enibriocorregnondente dy Academia Kussa de Ciencias e participul di; primejry expediço russa en redor do mundo. a de Krusenstern e Lisianiki

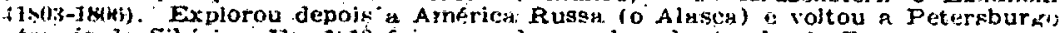

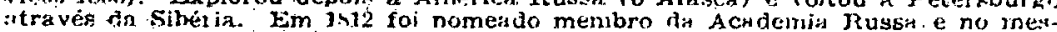
mo ano cónsul geral di Kússia no Brasil. Eni 1822-2s explorau por conty de

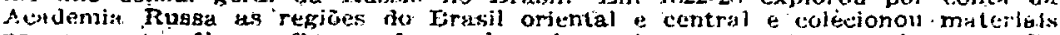

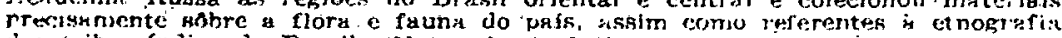
diss tribos fndias do Brasil. (Notan do tradutur).

(9). - D edificio năo ge assebielhava * um palácio: pertencin a um bartirular foj conmado pelo rei, porque nâo havir outro mellior: 
marmo-nos dêle, saudamo uma terceira vez. Depois disso êle ncs saudou e fêz dois passos em nossa direção. Langsdorf na qualidade de encarregado de negócios nos apresentou. Então o rei começou a falar comigo da nossa viagem, da corveta, perguntou se gostávamos do clima local e da cidade e após fazer uma dez perguntas, saudou-nos, desejando-nos boa viagem. Saímos recuando até a porta e fizemos cutra vez as três saudaçōes.

A chuva e um vento fresco do sul continuaram todo o dia 20. Resolvi então sair da baía com o intuito de afastar-me 80 ou 100 milhas das costas. Esperávamos encontrar ali um bom vento de sudeste ou de este e um tempo melhor.

Quero mencicnar a amabilidade e atenção que nos demcnstrou o capitão da corveta dos Estados Unidos da-América do Norte que se achava no Rio. Ele veiu primeiro fazer-me uma visita e ccnvidou-me para um almôço junto com o embaixador norte-americano e tôda a família dêste, à qual êle me apresentou. $O$ embaixador e sua família forsm musto amáveis comigo, do mesmo mcdo que os cutros convidados de outras nacionalidades. Pertencíamos a nove povos diferentes - russos, norte-americanos, inglêses, austriecos, holandeses, italianos do papa, venezianos, ilírios e franceses; mas não hâvia nenhum português nem brasileiro, donos daquele país. Encontrei também no Rio de Janeiro uma senhora de orígem tcheca, espôsa de uma cientista austríaco, que tinha chegado há pouco tempo. Essa pessoa tinha mcrado muito tempo em Moscou, na qualidade de governante duma familia de alta nobreza e falava russo muito bem. Era agradável encontrar tão longe da sue pátria gente que conhecia e falava o russo, língua tão pouco conhecida nos países estrangeiros.

\section{OBSERVAÇÓES A RESPEITO DO RIO DE JANEIRO E DO BRASIL EM GERAL.}

Rio de Janeiro, assim chamada na conversa habitual, ou cidade de São Sebastião do Rio de Janeiro, segundo as atas oficiais, é a capital do Brasil. Esta cidade ache-se numa vasta baía protegida de todos os ventos; os primeiros europeus que a visitaram, denominaram-na de "rio", pcis imaginavam que a baía fôsse um rio; após esta denominaçãa tornar-se de uso geral, nunca se pensou em modificá-la. A cidade está situada na margem sudoeste da baía, num lugar bem baixo e está rodeada de altas montanhas, ou melhor, está situada entre morros, pois há eleveções até no centro da cidede, nas quais são construidas igrejas e mosteiros. Esses morros escondem grande parte da cidade pera os navics que entram na baía e reduzem o espetáculo que se apresenta aos olhos. Também a vizinhança das grandes montanhas faz parecer menores todos os edifícios. Por isso, antes de desembarcar e visitar a cidade 
por dentro, ela nos parecia de pouca impcrtância, quando na realidade é bastante grande. As casas da cidade são geralmente feitas de tijolos e pintadas de branco: a maior parte delas tem dois andares, mas há também muitas de um andar; raras são as de três andares, pois não se constroem casas grandes, porque 0 govêrno logo se aproveita delas para alojar os funcionários e quase que as confisca aos proprietárics. Em muitas cesas de um ou dois andares há "acréscimes" cu super-estruturas:" umas em forma de áticos, outras de mirantes. Os habitantes gostam em geral de adornar suas casas. Em redor das portas e das janelas há madeira ou molduras de córes diferentes; nos cantcs colocam vasos e estatuetas. Isto tudo faz com que as ruas, em geral muito estreitas, sejam de uma estranha variedade de córes e aspectos. As ruas são pavimentadas de blocos de pedra com passeics estreitos.

Em tôda a cidade não há ưm único edifício, tanto ofiçial, como particular, que seja digno, da atenção de um europeu pelo seu tamanho ou pela beleza da sua arquitetura.

O palácio real, situado a beiramer, perto do cais principal, parece mais uma casa particular. Não há grandes igrejas, nem mosteiros; sòmente as fortalezes são bem construidas, mas ao que se afirma. nelas reina grande desordem. Nelas a entrada está proibida e por isso nāo pudemos vê-las por dentro.

O Rio de Janeiro possui 120.000 habitantes. Afirma-se que para cada homem branco há 15 pretos. Havia ali na época da nossa visita uns 4 ou 5 mil militares. Essa cidade é considerada o maior centro comercial do Brasil. Há ali agora 60 casas comerciais inglèsas que expcrtam grande quantidade de açúcar, arroz,algodão e café. Elas recebem essas mercadorias em troca de produtos ingléses. A província do Rio é connecida pelo seu ótimo café, a de. Pernambuco (os estrangeiros chamam às vêzes essa província de "Olinda", mas os portuguéses não conhecem outra denominação além de "Pernambuco"), pelo algodão e São Salvador (10) pelo melhor açúcar.

A população e a quantidade de produtos do Brasil aumentatam muito após a chegada da fémília real. Simultâneamente com o rei emigraram para o Ric de Janeiro 20.000 pờtuguêses e desde então chegam ininterruptamente portuguéses e estrangeircs, que compram terras e empreendem plantações; chegou ùltimamente um rico francés de .São-Domingos, comprou uma grande fazenda e empregou no trabalho 50 pretcs; em pouco tempo plantcu 50.000 pés de café. Ncsso cônsul Lengssoorf também comprou perto do Rio de Janeiro um terreno da superfície de uma légua portuguésa quadrada, pelo preço de 5.000 piastras. Planta aí czfé e já tem mais de 1.000 pés.

(19) - Os porqurueses não clamam essia provincia de Sũo Saltacior, mas ste Babia, quer dizer - Bahia de Todos os Santos. 
Antes da chegada da família real havia uma excessiva severidede para $\mathrm{ccm}$ os estrangeiros. Ninguém podia desembarcar sem ser acompanhado de um soldado, nem passear pela cidade sem escolta. Os estrangeiros não eram em geral autorizadcs a sair da cidade. Agora, ao contrário, êles gozam da mesma liberdade que nas capitais européias. Estivemos a 25 quilômetros da cidade səm sermcs acompanhados de um único pertuguês. Nossos barcos ${ }^{\circ}$ a remo nunca foram revistados, quando iam a terra; quanto a nós mesmos, tanto oficiais como marinheiros, passeávamos sem nenhum contrôle. Os estrangeiros estão também autcrizados agora a viajar pelo interior do Brasil e fazer suas observaçōes. Ũitimamente chegaram aqui uns cientistas austríacos e foram autorizados a viajar por tcdo o país, onde e como desejavam.

É digno de nctar também que não se proibem visitas às minés. Langsdorf esteve numa delas. A 'região onde se extrai o ouro está a 500 quilômetros de distância do Rio e chama-se "Minas". Todavia não há nela minas verdadeiras: a terra é tão rica em ouro, que quando lavada, acha-se nela bastante ouro. Todos estão autorizados a extraí-lo por êsse métcdo, com a condição de entregar uma quinta parte do curo ao rei. Os particulares estão também autorizados é extrair pedras precicsas, cedendo uma certa parte ao fisco.

Mas os diamantes, onde quer que sejam encontrados, pertencem ao rei e o govêrno toma as medidas mais severas para impedir sua exportação clandestin̊, nem sempre, aliás, com êxito. Ao que se afirma, o ccntrabandc dos diamantes atinge vultosas quantias cada ano. Há uns dez anos um cientista inglês que viajava. pelo Brasil, recebia autcrização para visitar as minas de diamantes sem ser revistado na saída (11). Usando dessa autorização, exportou grandes tesouros para Londres, onde abriu um comércio de pedras preciosas. Mâl pagou, porém, os fiscais portuguésés pela sua complacércia: publiccu um livro no qual descreveu todos os abusos e astúcias, usados no Brasil na exportaçãc clandestina dcs diamantes. Citou também: o nome dos funcionários que participaram dessas fraudes. Quendo o govêrno soube dêsse livro, fêz julgar todos os que fcram ncmeados nele e ordenou seu enforcamento.

No Rio de Jareiro pode-se abastecer de tudo o que for necessário para viver. Muitas coisas são, porém, importadas da Europa e são muito caras: por exemplo, as cebclas são importadas do Pôrto, as batatas, manteỉga e queijo da Irlanda e da Inglaterra; o gado é trazido do Rio Grande do Sul e por isso a carne é muito ruim e absolutamente sem gordura.

Nc que se refere cos prcdutos europeus, pcder-se-ia dizer que os inglêses inundam esta cidade com seus produtos. $O$ povo in-

(11). - Notenoss que iodos os que voltam das minas de diamantes gũo revistidos ia cabec; acs pés. São as rézes também desfeitas as gelas quebratis as malas parz cue os diamantes não sejan escondidos entre as táboas sestis. 
giés goxa aqui de grandes privilégios comerciais. Em primeiro lugar, os inglêses podem exportar para o Brasil todoc os produtos das suas fábricas e manufaturas, sem exceção alguma. Em segundo lugger, pagam um imposto de $15 \%$ sôbre as mercadorias importadas. ao passo que os próprios portuguêses pagam $16 \%$ e os cutrcs estrangeiros $24 \%$.

Os comerciantes ingléses aqui estabelecidos não importam nade por conta própria, mas recebem as mercadcrias da Inglaterra em consignação e cobram pela venda e pela transferência do dinheiro $7 \frac{1}{2} \%$, ao passo que para a compra e envio dos produtos locais recebem uma comissão de $5 \%$. Assim êles enriquecem ràpidamente e não correm o risco da falência.

Todavia maior lucro têm os capitalistas que emprestam dinheiro a juros elevados aos moços que resolvem fazer fortuna ccm - comércio na India ou na China. Isto se passa da seguinte maneira: um moço de boa conduta, que quer tentar fortuna no comércis e que mereceu a confiança de pessoas ricas, empresta o dinheiro sob a fiança dessas pessoas a $30-35 \%$ anuais, compra mercadorias $\epsilon$ vai com elas para a India. O empréstado paga $8 \%$ para segurar-se contra o naufrágio e outros acidentes de viagem. Assim ficam-lhe $22 \%$ garantidos. Em caso do devedor malcgrar no comércio cu ter calculado mal o negócio, a dívida é paga pelo fiador $\epsilon$, em caso de catástrofe marítima, pela agência de seguros (12).

Enfim, quero fazer algumas observaçōes a respeito dos abastecimentos que os navegadores cansados podem encontrar no Rio. E claro que cs navics que partem da Europa para grandes viagens abastecem-se em seus países de gêneros alimentícios, tais ccmo bolachas, carne salgada, óleo etc., de modo que durante a viagem necessitam só de gêneros alimentícios frescos que o Rio de Janeiro pode fornecer em grande quantidade a tôda um frota. E verdacie, que nem todes são da melnor qualidade: por exernplo, ccmo já disse, a carne de vaca e de carneiro é muito ruim, porque o gado é conduzido de longe, das províncias de Santa Catarina e do Rio Grande do Sul e mata-se antes que tentia o tempo para engcrdar. Vi rebanhos de bois trazidos para a cidade: só tinhsm ccur e e ossos e por isso a carne é sêca, dura e sem gordura nenhuma. Há muitas aves gostosas (galinhas, pates e perus) e que são bem barates.

Essa localidade abunda também em peixe. Forém, os navegadores que vão pescar na baía do Rio de Janeirs devem saber que há ali duas espécies de peixes venencsos, mas que rião são difíceis de distinguir: úm é semelhante à enguiz e é escorregadiço, e o

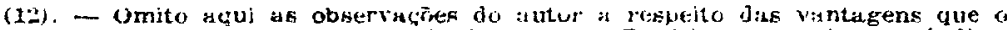
Yäo apresentava aos velulros en transito para o Pacifico un o dceano findico. riferentes a ventos que supra tritisat. (Not Ao trmeleter). 
outro é um peixe feio com urmim grande cabeça e um nariz semeThante ao das aves.

Quanto aos géneros alimentícios, o que há muito são as verduras; os mercadcs abundam delas, sobretudo de couve, alface, abóbora e rabanete. Também há muitas frutas nas diversas estaçōes do ano; quando estivemos no Rio era a época das melancias, das benanas, das laranjas, dos limões e de algumas outras frutas. Não havia abacexi maduro. Também são beratissimas as frutas cristalizadas.

A cebola, o coco e as batatas säo importadas e por isso näo são baratas, mas podem ser encontradas em qualquer quantidade.

A certá distância da cidade pode-se caçar a vontade; há muitas perdizes, pombas selvagens etc., mas um pouco longe para os navegantes de passagem poderem aproveitar-se da caça. Há tcdavia na baía, não lcnge do ancoradouro, uma: grande ilha (indicada nos mapas como ilha Real), que abunda em caça; nela porém é proibido pescar e caçar, pois é terreno reservado ao rei.

No Rio de Janeiro pcde-se ainda arranjar alguns gêneros alimentícios dos quais é bom abastecer-se, pois são ótimos alimentos para navegantes, como o arroz que é bom e barato, o rum que de início é bem ruim, mas que melhora com c tempo. Há também um produto que substitui o sagu: é ume semolina feita de raiz de mandioca e que se chama tapioca. A mandicca é uma planta muito conhecida de cuja raiz fazem farinha, utilizada na comida dos pretos; a tapioca é a parte melhor desta raiz.

No que se refere zo aparelh smento marítimo, êle existe no Rio, mas em pequena quantidade e é muito carc. A reparação dos navios é vagarosa e muito cara. Antes existia ali um estaleiro real, no quel se construiam navios, mas que foi suprimido por causa das dificuldedes do fornecimento da madeira. Ccnstroem-se agora navios em São Selvador onde há maiores florestes mais próximas da cidade. No arsenal do Rio de Janeiro quase nāo existe nada. Percorri-o em tôdas as direçōes e nada vi além de alguns velhos mastros e galeras reais meio pcdres scb a douradura.

A situeção geográfica do Rio de Janeirc, que está quase no trópico, pode fazer pensar que o calor é insuportável para os europeus, mas há os assim chamados ventos do mar, que existem em tôdas as regiōes quentes e que scpram do mar, com bastante fôrça, durante o dia todo. Esses ventos refrescem a atmosfera e tornam a estadia a beiramar não só tolerável, mas até agradável. No Rio de Janeiro o verto do mar sopra geralmente ao meio dia, vindo de leste e sopra quase todo o por do sol. Depois disso, durante algumas horas, reina a tranqüilidade; depois começam a soprar ventos leves, vindos de diferentes, rumos e assim até o nascer do sol. Depois disso vem a calmaria que continua até começar o vento marítimo. O meior calor é durante a calmaria matutina. Durante nossa estadia ali nunca excedeu $26^{\circ}$ Reaumur (ao meio dia), ao 
passo que a temperatura mais baixa foi de $14^{\circ}$ (durante a chuva). As medias diárias foram de $17^{\circ}$ a $20^{\circ}$. Estivemos no Rio de Janeiro, porém, no começo do verão quando o grande calor não tinha ainda começado, o que se dá em janeiro e fevereiro.

O tempo durante nossa estadia foi muito instável. De 17 dias que passámos na baía do Rio de Janeiro houve 5 dias em que chuviscava o dia todo e o tempo estava enccberto e escuto; isso sempre se dá quando os ventos vêm do sudoeste. Não houve ventos fcrtes durante ncssa estadia, sempre foram nioderados. Houve só uma trovoada, nāo muito fcrte, nem demorada. Os habitantes dizem que as trovoadas eram antes mais frequientes e fortes, mas tornaram-se mais raras após a chegada do rei.

No Rio de Janeiro o embaixador da Espanha, por intermédio do nosso consul, convidou-me para ir a sua casa e me pediu um favor muito importante para a côrte da Espanha e que consistia no seguinte: desde que os portuguêses se apossaram de Montevidéu as relações entre espanhóis e portuguêses tinham-se tornado péssimas. As grandes potências européias se encarregaram de ser os intermediários entre êsses dois países e receberam do embaixador portugués em París a promessa de que sua córte devolveria Montevidéu aos espanhóis. Na realidade, porém, mandavam-se constantemente reforços do Rio de Janeiro para lá e nesse momento estavam prontos três mil soldados afim de partir para Montevidéu. Quando o embaixador da Espanha pedia explicações, recebia respostas as mais impertinentes e altivas. "Cada missiva do gabinete brasileiro é uma verdadeira declaração de guerra", đisse-me êle, falando das notas que the dirigiu o ministério local.

O ministro espanhol devia avisar o.mais breve possivel o vicerei do Peru da situação entre as duas côrtes, assïm o exigia a segurança das possessões espanholas na América do Sul e, como êle não tinhá outro meio, recorreu a mim e me pediu que, em consideração à amizade e às boas disposiçōes do nosso monarca para $\mathrm{ccm}$ a Espania eu concordasse em tocar no Peru e levar para lá sua correspondência. Como eu tinha tempo para fazê-lo e como isso não encompridava minha viagem para o Kamtchatka, consenti de boa vontade em prestar ésse serviço à côrte da Espanha, o que, segundo as afirmações do nosso cônsul geral seria agradável à sua majestade imperial (13).

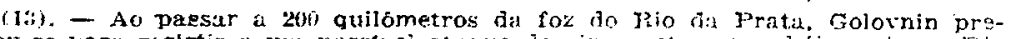
carou-se para resistir a uni possivei ataque dos insurretos espanhois, pois no Rio, (if Jareiro afirmava-sc que Esses "anotinudus" atacavari os navios de tôdas as nacionilitades, exceto os ingleses. Quanto tos russos eram considerados como ajiados do rei da Estanta. O navio de Golovnin encontrou na regiäo do Rio da

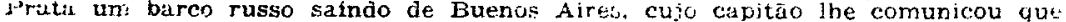
riäo somerate tinha sido bem tratado. mas que tm tocios os seus negúcios consarciais encontrou um tratamento justo e honesto. Alf he deram preferencia deante. cos conundantes dus outros barcos e de outra marteira rão era chamado senãu d. capitão de uma Erande naçio. (Nota du tradutor). 